\title{
ANALISIS KESESUAIAN BIAYA RIIL PASIEN KEMOTERAPI KANKER SERVIKS \\ DENGAN TARIF INA-CBG'S PADA PASIEN JKN RAWAT INAP \\ DI RSUP SANGLAH DENPASAR TAHUN 2014
}

\author{
(AN ANALYSIS ON THE COMPATIBILITY OF REAL COST AND INA-CBGS COST \\ DETERMINATION IN CERVICAL CANCER CHEMOTHERAPY PATIENT TO THE \\ IMPLEMENTATION OF NATIONAL HEALTH INSURANCE IN SANGLAH CENTRAL \\ GENERAL HOSPITAL OF DENPASAR IN 2014)
}

\author{
NI PUTU WINTARIANI ${ }^{\bullet}$, I PUTU TANGKAS SUWANTARA $^{2}$, NI MD. D. SHANTINI SUENA ${ }^{2}$ \\ ${ }^{1}$ Program Studi Farmasi Klinis, Institut Ilmu Kesehatan Medika Persada Bali \\ ${ }^{2}$ Program Studi D III Farmasi, Akademi Farmasi Saraswati Denpasar
}

\begin{abstract}
Abstrak: Kanker payudara adalah penyakit urutan pertama yang menyerang wanita di Indonesia. Tingginya biaya perawatan dan penggunaan sistem satu tarif Indonesia Case Base Group (INA-CBG) yang saat ini diikuti oleh semua rumah sakit di Indonesia. Tarif yang diputuskan oleh INA-CBG terkadang tidak sesuai dengan biaya sebenarnya yang dikeluarkan rumah sakit sehingga terjadi perbedaan. Penelitian ini bertujuan untuk mengetahui perbedaan biaya riil tanpa kemoterapi dan tarif INA-CBGs, komponen biaya tertinggi dengan biaya riil tanpa kemoterapi, dan untuk mengetahui jumlah biaya riil tanpa kemoterapi yang terkait dengan keteraturan siklus kemoterapi pada pasien rawat inap di serviks. Di Rumah Sakit Umum Sanglah Denpasar pada bulan Januari-Juli 2014. Penelitian ini menggunakan desain analisis deskriptif dengan mengumpulkan data dokumen klaim dan rekam medis penderita kemoterapi kanker payudara di RSUP Sanglah. Diambil secara purposive sampling secara retrospektif dengan desain cross-sectional menurut perspektif rumah sakit; Sampel terdiri dari 161 episode dari 50 pasien. Analisis dilakukan dengan menggunakan satu sampel uji-t untuk mengetahui perbedaan biaya riil dan tarif INA-CBG dan analisis multivariat untuk mengetahui faktor-faktor yang mempengaruhi biaya sebenarnya. Perbedaan antara biaya riil dan tarif paket INA-CBGs pada tingkat keparahan pertama sebesar Rp. 77.021.099 untuk yang pertama, Rp. 40.924 .685 untuk yang kedua, dan Rp 248.472.471 untuk kelas ketiga pengobatan; Pada tingkat keparahan kedua sebesar Rp 29.467.328 untuk yang pertama, Rp. 58.917.239 untuk yang kedua, dan Rp 170.277.952 untuk kelas ketiga perawatan, dan pada tingkat keparahan ketiga sebesar Rp 20.903.495 untuk yang pertama, Rp. 19.591.972 untuk yang kedua, dan Rp. 72.467.699 untuk kelas ketiga pengobatan. Faktor-faktor yang mempengaruhi biaya sebenarnya di kelas pertama, kedua, dan kelas ketiga adalah LOS $(\mathrm{p}=0.000)$, prosedur $(0.000)$, dan diagnosis sekunder $(\mathrm{p}=0,030)$. Pola siklus tidak teratur memiliki biaya rata-rata yang nyata tanpa kemoterapi yang lebih rendah daripada yang tidak teratur.
\end{abstract}

Kata Kunci: biaya, INA-CBG's, kanker serviks, kemoterapi, JKN.

\begin{abstract}
Breast cancer is the first sequence of most attacking women in Indonesia. The high cost of care and one using Indonesia Case Base Group (INA-CBG's) tariff package system currently followed by all hospitals in Indonesia. The tariff decided by INA-CBG's sometimes is not consistent with the real cost the hospital spends so that a difference occurs. This study aimed to find out the difference of real cost without chemotherapy and INA-CBGs tariff, the highest cost component in real cost without chemotherapy, and to find out the amount of real cost without chemotherapy related to the chemotherapy cycle regularity in cervical cancer inpatient in Sanglah Central General Hospital of Denpasar (RSUP Sanglah Denpasar) in January-July 2014. This study employed a descriptive analytical design by collecting the data of claim document and medical records of breast cancer chemotherapy inpatient in RSUP Sanglah (Sanglah Central General Hospital of Denpasar) taken using purposive sampling retrospectively with cross-sectional design according to the hospital's perspective; the sample consisted of 161 episodes from 50 patients. The analysis was carried out using one sample t-test to find out the difference of real cost and INA-CBG tariff and multivariate analysis to find out the factors affecting the real cost. The difference between real cost and INA-CBGs package tariff in the first severity level of IDR 77,021,099 for the first, IDR 40,924,685 for the second, and IDR 248,472,471 for the third class of treatment; in the second severity level of IDR 29,467,328 for the first, IDR 58,917,239 for the second, and IDR 170,277,952 for the third class of treatment, and in the third severity level of IDR
\end{abstract}

• email korespondensi: putuwinta@gmail.com 
20,903,495 for the first, IDR 19,591,972 for the second, and IDR 72,467,699 for the third classes of treatment. The factors affecting the real cost in the first, second, and third classes of treatment were LOS $(p=0.000)$, procedure $(0.000)$, and secondary diagnose $(\mathrm{p}=0.030)$. The irregular cycle pattern had average real cost without chemotherapy lower than the irregular one.

Keywords: Cervical Cancer, Chemotherapy, Cost, INA-CBG's, JKN.

\section{PENDAHULUAN}

Undang-Undang Republik Indonesia No. 36 Tahun 2009 menyebutkan bahwa kesehatan merupakan hak asasi manusia dan salah satu unsur kesejahteraan yang harus diwujudkan sesuai dengan cita-cita bangsa Indonesia. Beban ekonomi semakin berat karena semakin tinggi angka kesakitan sehingga berdampak pada tingginya biaya kesehatan (Depkes, 2009).

Solusi pemerintah untuk mengatasi masalah mengenai biaya kesehatan yaitu dengan sistem jaminan kesehatan. Penerapan konsep INA-CBG's (Indonesia Case Base Groups) ditetapkan oleh Kementerian Kesehatan Republik Indonesia sebagai sistem pembayaran pelayanan kesehatan. Hal ini sesuai dengan Keputusan Menteri Kesehatan RI Nomor 903/Menkes/Per/V/2011 tentang Pedoman Pelaksanaan Program Jaminan Kesehatan Masyarakat (Jamkesmas) tahun 2011. Sistem pembayaran INA-CBG's merupakan pembayaran berdasarkan tarif pengelompokan diagnosis yang mempunyai kedekatan secara klinis dan homogenitas sumber daya yang dipergunakan.

WHO (World Health Organization) menyatakan bahwa kanker merupakan problem kesehatan yang sangat serius karena jumlah penderitanya meningkat sekitar $20 \%$ per tahun. Salah satu jenis kanker yaitu kanker serviks merupakan urutan pertama terbanyak menyerang kaum wanita di Indonesia (Emilia,2010). Kejadian kanker di Indonesia masih belum dapat diketahui secara pasti, karena belum ada registrasi kanker berbasis populasi yang dilaksanakan.

Rumah Sakit Umum Pemerintah (RSUP) Sanglah Denpasar cukup representatif untuk dijadikan objek penelitian karena RSUP Sar ${ }_{1} \mathrm{~h}$ Denpasar merupakan Rumah Sakit tipe A $1 \frac{\mathrm{g}}{\mathrm{g}}$ melayani masyarakat dan berfungsi sebagai teaching hospital serta merupakan Rumah Sakit rujukan. Kendala-kendala dalam pelaksanaan Jaminan Kesehatan Nasional (JKN) di rumah sakit rujukan bisa saja terjadi, terlebih lagi dalam hal klaim pembayaran sehingga tidak menutup kemungkinan kejadian ini terjadi pada pasien JKN kemoterapi pada kanker serviks. Penyakit terbesar kedua di RSUP Sanglah Denpasar adalah kanker serviks setelah kanker payudara, sedangkan untuk kemoterapi pada tahun 2012 menghabiskan dana paling besar di RSUP Sanglah Denpasar.

Kemoterapi diberikan dalam suatu siklus, artinya suatu periode pengobatandiselingi dengan periode pemulihan, lalu dilakukan pengobatan dan diselingidengan pemulihan begitu seterusnya. Pemberian kemoterapi dalam siklus inibertujuan untuk memberi kesempatan pada sel sehat untuk tumbuh danberkembang (NCI, 2013). Pasien yang menjalani tidak semuanya menjalani siklus kemoterapi dengan lengkap. Penggunaan kemoterapi juga dapat menimbulkan berbagai masalah seperti efek samping dan toksisitas sehingga terjadi penundaan pemberian siklus kemoterapi dimana hal ini dapat mempengaruhi besar biaya yang perlu dikeluarkan oleh pasien.

Menurut penelitian Oktaviani (2012) di RSUD Dr. Moewardi dengan menggunakan uji Chi Square menunjukkan bahwa ada hubungan antara LOS, faktor pasien (jumlah paritas) dan faktor penyakit (comorbid dan tingkat keparahan) dengan biaya pengobatan kanker serviks rawat. Rata-rata biaya pengobatan kanker serviks berdasarkan tarif RSUD Dr. Moewardi pada tingkat keparahan I: pembedahan Rp. 2.893.243 \pm Rp. 1.531.975, kemoterapi Rp. 3.313.342 \pm Rp. 2.386.899, radioterapi Rp. 3.988.027 \pm Rp. 2.912.931, dan radical hysterectectomy $\mathrm{Rp} .10 .039 .072 \pm \mathrm{Rp}$. 1.331.822. Tingkat keparahan II: pembedahan Rp. 5.885.859 \pm Rp. 4.059.020 dan kemoterapi Rp. 4.474.084 \pm Rp. 2.588.966. Tingkat keparahan III: radical hysterectectomy $\mathrm{Rp} . \quad 13.347 .209 \pm$ Rp.2.852.551. ALOS (Average Length of Stay) rumah sakit lebih lama dibandingkan dengan $A L O S$ INA-DRG kecuali pada tingkat keparahan III, hal ini berpengaruh pada biaya pengobatan kanker serviks yang secara umum lebih tinggi dibandingkan tarif paket INA-DRG. Hal ini menunjukkan bahwa belum efisiennya implementasi $I N A-D R G$ untuk pengobatan kanker serviks pada pasien Jamkesmas di RSUD Dr. Moewardi.

Berdasarkan latar belakang tersebut diharapkan penelitian ini dapat memberikan gambaran biaya pengobatan untuk kemoterapikankerserviks sebagai pertimbangan dalam penetapan pembiayaan kesehatan berdasarkan INA-CBG's. 


\section{METODE PENELITIAN}

Penelitian ini menggunakan metode penelitianian dekskritif analitik, data penelitian ini merupakan data kuantitatif, metode pengambilan data dilakukan secara retrospektif, yaitu diambil dari penelusuran dokumen rekam medis pasien dan data biaya pengobatan pasien rawat inap JKN kemoterapi pada kanker payudara yang menggunakan regimen kemopterapi di RSUP Sanglah.

Penelitian ini dilakukan di ruanagna rekam medik Rumah Sakit Umum Pusat (RSUP) Sanglah Denpasar yang berlokasi di Jalan Pulau Nias Denpasar-Bali. Data yang diambil bersifat retrospektif.

Variabel bebas (Independent Variable) dari penelitian ini adalah penggunaan jenis regimen kemoterapi RSUP Sanglah. Variabel terikat (Dependent Variable) adalah perbedaan biaya pengobatan berdasarkan regimen pengobatan pasien kemoterapi kanker payudara di RSUP Sanglah.

Alat yang digunakan adalah Lembar Pengumpul Data (LPD) pasien kemoterapi kanker payudara yang menggunakan regimen kemoterapi. LPD berisi nomor rekam medik, umur, tanggal masuk rumah sakit, tingkat keparahan, regimen yang digunakan dan biaya per pasien kemoterapi pada kanker payudara yang menggunakan regimen kemoterapi.

Bahan yang diteliti adalah catatan rekam medik pasien kemoterapi pada kanker payudara yang menggunakan regimen kemoterapi, data biaya pengobatan dan jenis regimen kemoterapi.

Tenik pengambilan data dengan menggunakan Metode pengambilan data dilakukan secara retrospektif, yaitu diambil dari penelusuran dokumen rekam medis pasien dan data biaya pengobatan pasien rawat inap JKN kemoterapi pada kanker payudara yang menggunakan regimen kemopterapi di RSUP Sanglah.

\section{Analisis Hasil}

\section{Analisis deskripsi}

Analisis deskripsi menyajikan data dalam bentuk statistik yang berfungsi mendeskripsikan atau memaparkan biaya riil pasien rawat inap JKN kemoterapi pada kanker serviks antara lain umur, dan tingkat keparahan. Perbedaan biaya riil dengan tarif INA-CBG's diperoleh dari total tarif INACBG's dikurangkan dengan total biaya riil.
2. Kesesuaian biaya riil dengan tarif INACBG's

Analisis kesesuaian biaya riil dengan tarif INA-CBG's dilakukan dengan one sample test, membandingkan antara rata-rata biaya pengobatan pasien rawat inap kemoterapi pada kanker serviks di rumah sakit dengan tarif INA-CBG's.

3. Komponen yang mempengaruhi perbedaan biaya riil dengan tarif INACBG's

Dilakukan dengan analisis multivariat, yaitu untuk mengetahui komponen biaya obat dan alat kesehatan, biaya pengobatan, dan biaya penunjang medik terhadap perbedaan biaya riil dengan tarif INA-CBG's pada pasien kemoterapi pada kanker serviks JKN di RSUP Sanglah Denpasar.

\section{Analisis siklus kemoterapi}

Analisis pengaruh kesesuaian tercapainya satu seri kemoterapi untuk melihat bagaimana pengaruh jika tercapainya satu seri kemoterapi sesuai dengan jadwal yang ditetapkan terhadap biaya riil. Dalam analisis ini peneliti menentukan satu seri kemuterapi yang minimal telah melakukan 4 episode kemoterapi.

\section{HASIL DAN PEMBAHASAN}

\section{Analisis Deskriptif}

\section{a. Karakteristik pasien}

Gambaran karakteristik subyek penelitian berdasarkan umur dapat dilihat pada gambar 1 .

Berdasarkan sosiodemografi dari data kanker serviks yang dirawat di RS Pirngadi Medan (RSPM), 89\% wanita telah menikah menderita penyakit itu, dengan penderita tertinggi pada umur 40-49 tahun, semakin tua usia seseorang, maka semakin meningkat risiko terjadinya kanker serviks (Widyastuti, 2011). Pada penelitian ini umur 41-50 dan 51-60 merupakan umur tertinggi penderita kanker serviks, sedangkan umur 61-71 terjadi penurunan angka penderita kanker serviks kemungkinan disebabkan daya tahan tubuh pasien melemah akibat umur yang sudah lanjut sehingga menyebabkan pasien tidak mampu menahan penyakitnya (pasien meninggal).

Peningkatan terjangkitnya penyakit kanker serviks disebabkan karena terjadi penurunan elastisitas dinding serviks, dan penurunan sekresi cairan vagina yang mengakibatkan terjadinya lesi pada dinding serviks, kemudian ada beberapa faktor selain faktor di atas yaitu proses menopause 
yang mempengaruhi hormon sehingga dapat memicu terjadinya kanker serviks itu sendiri (Movva et al, 2009). Diananda (2007) mengatakan bahwa meningkatnya risiko kanker leher rahim pada usia lanjut merupakan gabungan dari meningkatnya dan bertambah lamanya waktu pemaparan terhadap karsinogen serta makin melemahnya sistem kekebalantubuh akibat usia. Sehingga sistem kekebalan tubuh yang lemah dapat menyebabkan tingginya resiko efek samping dari kemoterapi sehingga dapat meningkatkan penggunaan obat baru dan memperpanjang LOS pasien.

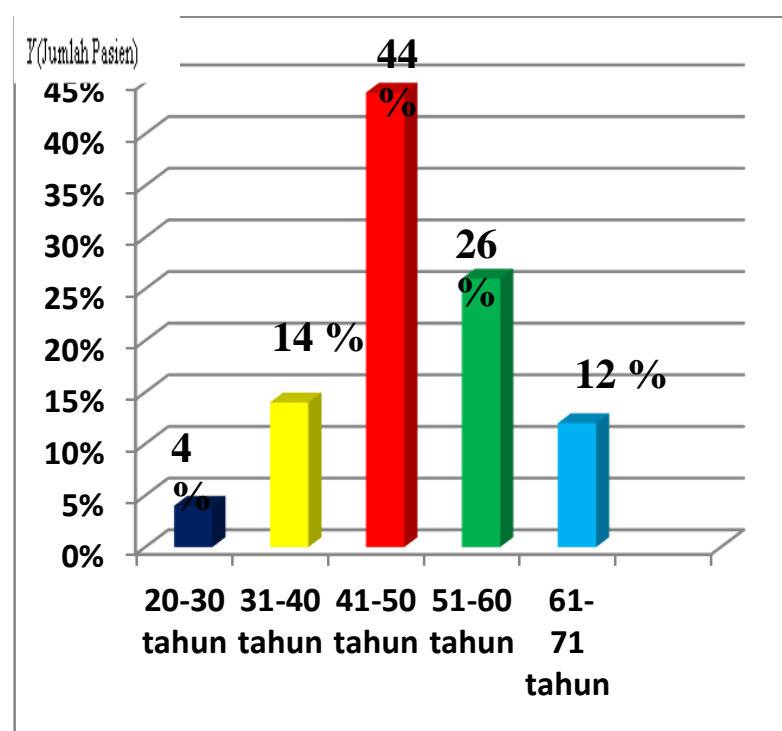

Gambar 1. Karakteristik Subyek Penelitian Berdasarkan Umur

\section{b. Karakteristik Episode Perawatan Pasien}

Kelas perawatan pasien kemoterapi kanker serviks dibagi menjadi 3 kelas antara lain kelas I, kelas II, dan kelas III. Berdasarkan hasil penelitian di RSUP Sanglah yang tertera pada tabel 3 menunjukkan bahwa insidensi kemoterapi kanker serviks terbanyak menjalani perawatan pada kelas III yaitu sebanyak 113 episode $(70,2 \%)$ dari total 161 episode. Kelas III insidensi terbanyak dikarenakan pasien yang sebelumnya menerima bantuan biaya kesehatan berupa jamkesmas secara otomatis dimasukkan pembiayaannya ke dalam tarif INA-CBG's untuk kelas perawatan III.

Kelas III merupakan kelas yang pembayaran iurannya paling rendah dibandingkan dengan kelas I dan kelas II sehingga lebih terjangkau dan pembayarannya bisa disesuaikan dengan tingkat penghasilan dari pasien. Seperti yang telah ditetapkan oleh Peraturan Presiden Nomor 111 tahun 2013 jenis iuran dibagi menjadi: 1) iuran jaminan kesehatan bagi penduduk yang didaftarkan oleh pemerintah daerah dibayarkan oleh pemerintah daerah (orang miskin dan tidak mampu). 2) Iuran Jaminan Kesehatan bagi peserta Pekerja Penerima Upah yang terdiri dari atas PNS, Anggota TNI, Anggota Polri, Pejabat negara, Pegawai Pemerintah Non Pegawai Negeri akan dipotong sebesar 5\% dari gaji atau upah per bulan, dengan ketentuan 3\% dibayar oleh pemberi kerja, dan 2\% dibayar oleh peserta. 3) Peserta Perorangan akan membayar iuran sebesar kemampuan dan kebutuhannya yaitu untuk mendapat fasilitas kelas I dikenai iuran $\mathrm{Rp} 59.500$ per orang per bulan, kelas II dikenai iuran Rp. 42.500 per orang per bulan dan kelas III dikenai iuran Rp 25.000 per orang per bulan.

\section{c. Distribusi tingkat keparahan}

Tingkat keparahan dipengaruhi oleh banyaknya penyakit penyerta atau comorbid yang di derita pasien, dibuktikan bahwa kondisi emosional seseorang akan mempengaruhi tingkat kekebalan tubuh manusia (Saragih, 2010). Pasien pada tingkat emosional yang rapuh akan lebih cepat tertularkan penyakit, karena tingkat kekebalan tubuhnya menurun akibat kondisi emosi yang buruk. Kondisi emosi yang positif, penuh pengharapan, akan meningkatkan daya tahan tubuh pasien kemoterapi kanker serviks sehingga comorbidbisa dicegah.

Tabel 3 menunjukkan bahwa tingkat keparahan I sebanyak 110 episode (68,3\%), keparahan II sebanyak 39 episode $(24,2 \%)$, dan keparahan III sebanyak 12 episode $(7,5 \%)$. Berdasarkan hasil yang diperoleh dapat dikatakan episode kemoterapi tingkat keparahan I lebih besar dibandingkan dengan tingkat keparahan II dan III.

Tabel 1. Karakteristik Episode keparahan, Diagnosis Sekunder dan Prosedur pasien dengan kode INA-CBG's C-4-13-I/II/III yang menjalani rawat inap di RSUP Sanglah Denpasar periode Januari-Juli 2014

\begin{tabular}{|c|c|c|c|c|}
\hline $\begin{array}{c}\text { Karakteristik } \\
\text { episode } \\
\text { perawatan }\end{array}$ & $\begin{array}{c}\text { Varian } \\
\text { kelompok }\end{array}$ & $\begin{array}{c}\text { Jumlah } \\
\text { episode } \\
\text { perawatan }\end{array}$ & $\begin{array}{c}\text { Persentase } \\
(\%)\end{array}$ & $\begin{array}{c}\text { Total } \\
\text { episode }\end{array}$ \\
\hline \multirow{3}{*}{$\begin{array}{l}\text { Kelas } \\
\text { perawatan }\end{array}$} & Kelas I & 27 & $16,8 \%$ & \multirow{3}{*}{161} \\
\hline & Kelas II & 21 & $13 \%$ & \\
\hline & Kelas III & 113 & $70,2 \%$ & \\
\hline \multirow{3}{*}{$\begin{array}{l}\text { Tingkat } \\
\text { keparahan }\end{array}$} & c-4-13-I & 110 & 68,3 & \multirow{3}{*}{161} \\
\hline & c-4-13-II & 39 & $24,2 \%$ & \\
\hline & c-4-13-III & 12 & $7,5 \%$ & \\
\hline \multirow{4}{*}{$\begin{array}{l}\text { Jumlah } \\
\text { diagnosa } \\
\text { sekunder }\end{array}$} & 1 diagnosa & 89 & $55,3 \%$ & \multirow{4}{*}{161} \\
\hline & sekunder & & & \\
\hline & $\begin{array}{l}2 \text { diagnosa } \\
\text { sekunder }\end{array}$ & 33 & $20,5 \%$ & \\
\hline & $\begin{array}{l}3 \text { diagnosa } \\
\text { sekunder }\end{array}$ & 39 & $24,2 \%$ & \\
\hline
\end{tabular}




\begin{tabular}{lcccc}
\hline $\begin{array}{c}\text { Karakteristik } \\
\text { episode } \\
\text { perawatan }\end{array}$ & $\begin{array}{c}\text { Varian } \\
\text { kelompok }\end{array}$ & $\begin{array}{c}\text { Jumlah } \\
\text { episode } \\
\text { perawatan }\end{array}$ & $\begin{array}{c}\text { Persentase } \\
\mathbf{( \% )}\end{array}$ & $\begin{array}{c}\text { Total } \\
\text { episode }\end{array}$ \\
\hline Prosedur & 1 prosedur & 97 & $60,24 \%$ & \\
& 2 prosedur & 48 & $29,8 \%$ & 161 \\
& 3 prosedur & 16 & $9,93 \%$ & \\
\hline
\end{tabular}

Besar episode perawatan pada tingkat keparahan I karena RSUP Sanglah Denpasar merupakan rumah sakit rujukan pasien kanker di daerah Bali, NTB (Nusa Tenggara Barat), NTT (Nusa Tenggara Timur), dan sebagian pasien kemoterapi kanker serviks ada juga yang berasal dari wilayah jawa timur. Rendahnya episode perawatan pada tingkat keparahan II dan III disebabkan karena penanganan yang intensiv pada proses pengobatan di RSUP Sanglah sehingga mampu mencegah terjadinyaproses metastase pada sel kanker dan mengurangi jumlah komplikasi yang diderita pasien sehingga dapat mengurangi jumlah pasien yang masuk dalam kategori tingkat keparahan II dan III.

\section{Kesesuaian biaya riil dengan tarif INA- CBG's}

Berdasarkan hasil pada tabel 2, menunjukkan bahwa terdapat selisih antara biaya riil dengan tarif paket INA-CBG's. Selisih yang paling besar diperoleh pada tingkat keparahan I (C-4-13-I) karena jumlah episode perawatan pada tingkat keparahan I lebih besar yaitu total 109 episode perawatan dibandingkan dengan jumlah total episode perawatan pada tingkat keparahan II dan III masing-masing total 39 dan 12 episode perawatan.

Tabel 2. Data Biaya Riil tanpa Kemoterapi dan Total Biaya INA-CBG's sesuai Kategori Pasien

\begin{tabular}{lccccc}
\hline Kategori & Episode & $\begin{array}{c}\text { Total Biaya Riil } \\
\text { Tanpa } \\
\text { Kemoterapi } \\
(\mathbf{R p})\end{array}$ & $\begin{array}{c}\text { Total Biaya } \\
\text { INA-CBG's } \\
(\mathbf{R p})\end{array}$ & Selisih $(\mathbf{R p )}$ & $\begin{array}{c}\text { Rerata Selisih } \\
\text { Per Episode } \\
\text { (Rp) }\end{array}$ \\
\hline C-4-13-I & & & & & \\
Kelas I & 21 & 31.628 .367 & 108.649 .466 & 77.021 .099 & 3.667 .671 \\
Kelas II & 11 & 7.446 .646 & 48.371 .331 & 40.924 .685 & 3.720 .425 \\
Kelas III & 77 & 44.732 .167 & 293.204 .638 & 248.472 .471 & 3.226 .915 \\
\hline Total & 109 & 83.807 .180 & 450.225 .435 & 366.418 .255 & 3.361 .635 \\
\hline C-4-13-II & & & & & \\
Kelas I & 4 & 6.946 .912 & 36.414 .240 & 29.467 .328 & 7.366 .832 \\
Kelas II & 8 & 6.908 .508 & 65.825 .747 & 58.917 .239 & 7.364 .654 \\
Kelas III & 27 & 18.795 .974 & 189.073 .926 & 170.277 .952 & 6.306 .590 \\
\hline Total & 39 & 32.651 .394 & 291.313 .913 & 258.662 .519 & 6.632 .372 \\
\hline C-4-13-III & & & & & \\
Kelas I & 2 & 2.301 .780 & 23.205 .275 & 20.903 .495 & 10.451 .747 \\
Kelas II & 2 & 1679530 & $21,271,502$ & 19.591 .972 & 9.795 .986 \\
Kelas III & 8 & 4.883 .221 & 77.350 .920 & 72.467 .699 & 9.058 .462 \\
\hline Total & 12 & 8.864 .531 & 121.827 .697 & 112.963 .166 & 9.413 .597 \\
\hline
\end{tabular}

Pada kelas perawatan, selisih yang paling besar diperoleh dari tingkat keparahan I pada kelas perawatan III denganjumlah 77 episode perawatan, jumlah episode cukup banyak dibandingkan dengan jumlah episode tingkat keparahan II dan tingkat keparahan III pada masing-masing kelas perawatan. Tarif paket INA-CBG's tingkat keparahan I pada kelas perawatan IIImemang lebih sedikit dibandingkan dengan kelas perawatan I sebanyak Rp 5.209.221dan II sebanyak Rp 4.465.046yaitu masing-masing untuk kelas perawatan III dengan tingkat keparahan I yaitu Rp 3.720.871, tingkat keparahan II yaitu Rp 7.002.738 dan tingkat keparahan III yaitu Rp 9.668.865. Meskipun jumlah episode perawatan cukup besar yaitu 77 episode perawatan dan paket tarif INA-
CBG's yang rendah yaitu Rp 3.720.871, namun RSUP Sanglah Denpasar sudah melaksanakan penanganan yang intensiv pada proses pengobatan sehingga mengurangi jumlah komplikasi yang diderita pasien dan mengurangi jumlah pasien yang masuk dalam kategori tingkat keparahan II dan III, sehingga berdampak pada kapasitas tarif INACBG's yang tidak melebihi batas yang sudah dianggarkan.

\section{Komponen yang mempengaruhi perbedaan biaya riil dengan tarif INA-CBG's}

Faktor yang mempengaruhi biaya riil Uji Analisis korelasi multivariat dilakukan untuk mengetahui apakah umur, LOS, diagnosis 
sekunder dan prosedur mempengaruhi biaya riil pada pasien kanker serviks.

Hasil menunjukkan faktor yang mempengaruhi biaya riil tanpa kemoterapi pada tingkat keparahan I yaitu $\operatorname{LOS}(p=0,000)$, prosedur $(p=0,011)$, kelas perawatan $(p=0,000)$. Faktor yang mempengaruhi biaya riil tanpa kemoterapi pada tingkat keparahan II yaitu LOS $(p=0,000)$, prosedur $(p=0,000)$, dan kelas perawatan $(\mathrm{p}=0,001)$. Tingkat keparahan III yaitu LOS $(p=0,009)$, Prosedur $(p=0,039)$, dan kelas perawatan $(p=0,002)$. Sehingga dapat dinyatakan bahwa LOS, prosedur, dan kelas perawatan mempengaruhi biaya riil tanpa kemoterapi pada tingkat keparahan I, II dan III, secara signifikan. Nilai $r$ pada LOS, prosedur memiliki nilai positif sehingga semakin besar jumlah LOS dan prosedur maka semakin tinggi biaya riil. Nilai $r$ pada kelas perawatan bernilai positif, karena semakin tinggi kelas perawatannya, dalam penelitian ini kelas tertinggi biayanya adalah kelas perawatan I maka semakin tinggi biaya riil tanpa kemoterapi pasien.

Serangkaian prosedur pengobatan yang harus dijalani oleh pasien kemoterapi kanker serviks, menyebabkan LOS pasien bertambah panjang. LOS yang panjang berhubungan dengan karakteristik dari masing-masing pasien dalam menghadapi pengobatan kemoterapi. Seperti yang dikatakan oleh Permono (2006) yaitu pengaruh obat terhadap perjalanan kanker tergantung dari jenis obat, dosis, cara pemberian, lama pemberian, farmakokinetik, biologi kanker, ketersediaan obat dan toleransi tubuh pasien. Kejadian cleareance (pembersihan) obat antar pasien bervariasi sangat besar. Perbedaan tersebut, meskipun dengan dosis yang sama, cleareance berkisar antara dua sampai sepuluh kali lipat. Kali ini akan berpengaruh pada kadar obat dalam plasma dan dalam sel kanker dengan segala efek baik dan buruknya. Sehingga perbedaan ini menyebabkan LOS dan prosedur sangat mempengaruhi biaya riil pasien pada kelas keparahan I dan II.
Tobias \& Hochhauser (2010) mengatakan efek samping yang timbul akibat pemberian kemoterapi ini sangat mengganggu pasien, oleh sebab itu pasien diberikan premedikasi untuk mencegah rasa tidak nyaman tersebut muncul. Premedikasi yang umum diberikan pada pasien kanker serviks yang mendapatkan kemoterapi adalah antiemetik dan analgetik karena efek samping yang paling sering terjadi dan paling mengganggu akibat pemberian agen kemoterapi adalah mual muntah dan rasa sakit (nyeri). LOS yang panjang, kemungkinan disebabkan karena pasien masih merasakan atau tidak bisa menahan rasa efek samping kemoterapi yang hebat, sampai harus melakukan perawatan di rumah sakit lebih lama, sehingga LOS menjadi lebih panjang dan menyebabkan pengaruh terhadap biaya riil pasien.

\section{Analisis siklus kemoterapi}

Analisis pola siklus kemoterapi dilakukan untuk melihat siklus kemoterapi pasien. Dalam penelitian ini, peneliti menetapkan minimal siklus kemoterapi yang dilakukan adalah minimal 4 siklus kemoterapi karena penelitian hanya menggunakan data dari bulan Januari-Juli 2014. Siklus kemoterapi dilihat berdasarkan data pasien yang mendapatkan minimal 4 kali siklus kemoterapi dan biaya per siklus kemoterapi. jumlah total pasien yang memenuhi kriteria minimal 4 siklus kemoterapi dari semua tingkat keparahan dan kelas perawatan berjumlah 17 pasien dengan total jumlah episode perawatan 76 episode. Terdapat 9 pasien yang menjalani 4 siklus kemoterapi dan 8 pasien dengan 5 siklus kemoterapi. Pasien yang menjalani kemoterapi tidak semuanya menjalani siklus kemoterapi dengan lengkap. Ada banyak faktor yang menyebabkan ketidaklengkapan siklus yang diterima oleh pasien antara lainbiaya, kondisi pasien, serta efek samping pemberian kemoterapi yang dirasa sangat mengganggu pasien (Zaenal, 2011).

Tabel 3.Pola Siklus kemoterapi pasien kemoterapi kanker serviks rawat inap di RSUP Sanglah Denpasar periode Januari-Juli 2014

\begin{tabular}{cccccc}
$\begin{array}{c}\text { Jumlah } \\
\text { pasien }\end{array}$ & $\begin{array}{c}\text { Keteraturan } \\
\text { siklus }\end{array}$ & $\begin{array}{c}\text { Rata-rata } \\
(\mathbf{R p})\end{array}$ & $\begin{array}{c}\text { Total biaya riil } \\
\text { tanpa } \\
\text { kemoterapi } \\
(\mathbf{R p})\end{array}$ & $\begin{array}{c}\text { Total tarif } \\
\text { INA-CBG's } \\
(\mathbf{R p})\end{array}$ & Selisih (Rp) \\
\hline 4 & Teratur & 2.709 .665 & 10.838 .660 & 123.730 .957 & 112.892 .297 \\
\hline 13 & Tidak teratur & 3.863 .903 & 50.230 .746 & 246.436 .830 & 196.206 .084 \\
\hline
\end{tabular}

Pasien dengan interval siklus kemoterapi teratur memiliki rata-rata biaya yang lebih kecil daripada biaya pasien yang interval siklus kemoterapinya tidak teratur. Kemoterapi diberikan secara berkala untuk meminimalkan jumlah sel kanker yang dapat menimbulkan kerusakan pada 
sel sehat sehingga menimbulkan beberapa gejala yang dirasakan mengganggu bagi pasien (efek samping). Hal ini sesuai dengan teori yang disampaikan oleh Smeltzer \& Bare (2002) semakin banyak frekuensi pemberian kemoterapi maka akan semakin banyak sel kanker mengalami kerusakan dan kematian, demikian juga pada sel sehat dalam tubuh, setelah beberapa periode, 2-4 minggu sel sehat pulih kembali namun mengalami kerusakan yang berarti sehingga akan mengalami penurunan fungsi dan ketahanan tubuh pasien juga akan menurun hal ini akan terus berlanjut pada pemberian kemoterapi berikutnya, seperti yang dinyatakan oleh Dipiro, et al yaitu diperlukan jeda pemberian siklus kemoterapi 3-4 minggu (21-28 hari) setelah pemberian kemoterapi.Kemoterapi yang tidak lengkap siklusnya, akan menyebabkan resiko meninggal yang lebih besar sebanyak $8,63 \mathrm{kali}$ lebih besar dibanding dengan penderita yang mendapat pengobatan secara lengkap (Sirait,2003).Stresor yang muncul selama pengobatan kanker seperti efek samping pengobatan yang menyakitkan, depresi yang dialami oleh pasien, lamanya waktu pengobatan, tingginya biaya pengobatan, dan kualitas komunikasi antara petugas medis dengan pasien yang rendah, dapat mengakibatkan pasien tidak konsisten menjalani pengobatan (Pertiwi, 2012).

\section{KESIMPULAN}

Faktor-faktor yang mempengaruhi biaya riil tanpa kemoterapi pada setiap tingkat keparahan pasien rawat inap JKN kemoterapi kanker serviks di RSUP Sanglah Denpasar yaitu: 1) Faktor yang mempengaruhi biaya riil tanpa kemoterapi pada tingkat keparahan Iyaitu LOS $(\mathrm{p}=0,000)$, prosedur $(\mathrm{p}=0,011)$, kelas perawatan $(\mathrm{p}=0,000) ; 2)$ Faktor yang mempengaruhi biaya riil tanpa kemoterapi pada tingkat keparahan II yaitu LOS $(\mathrm{p}=0,000)$, prosedur $(\mathrm{p}=0,000)$, kelas perawatan $(\mathrm{p}=0,001) ; 3)$ Faktor yang mempengaruhi biaya riil tanpa kemoterapi pada tingkat keparahan III yaitu LOS $(p=0,009)$, Prosedur $(p=0,039)$, dan kelas perawatan $(p=0,002)$.

Pola siklus tidak teratur berjumlah 13 pasien memiliki rerata biaya riil tanpa kemoterapi yang lebih besar yaitu $\mathrm{Rp} 3.863 .903$ dibandingkan denganpola siklus kemoterapi teratur yang berjumlah 4 pasien yaitu $\mathrm{Rp} 2.709 .665$.

\section{UCAPAN TERIMAKASIH}

Puji syukur kehadapan Tuhan Yang Maha Esa, penulis dapat menyelesaikan penyusunan jurnal yang berjudul "Analisis Kesesuaian Biaya Riil Pasien Kemoterapi Kanker Serviks Dengan Tarif Ina-Cbg's Pada Pasien Jkn Rawat Inap Di Rsup Sanglah Denpasar Tahun 2014". Penulis menyadari jurnal ini tidak akan selesai tanpa bantuan berbagai pihak. Penulis mengucapkan terimakasih kepada Direktur Rumah Sakit Umum Pemerintah (RSUP) Sanglah Denpasar yang sudah memfasilitasi penelitian ini sehingga penulis dapat menyelesaikan jurnal ini.

\section{DAFTAR PUSTAKA}

Amir, A. S., 2012., Evaluasi Penerapan Sistem Biaya Berbagi Kemoterapi Pasien Kanker Serviks di RSUD Dr. Moewardi Surakarta (Tesis). Surakarta: Fakultas Farmasi, Universitas Setia Budi.

Andayani, T. M., 2013, Farmakoekonomi Prinsip dan Metodelogi, Cetakan pertama, Yogyakarta: Bursa ilmu. Hal 20-24.

Bootman, J. L., Townsend R. J., McGhan W. F., 2005, Principles of Pharmacoeconomics, 118, Harvey Whitney Books Company, Ohio.

Brunner dan Suddarth, 2002, Keperawatan Medikal-Bedah, Hal: 1559, Penerbit Buku Kedokteran EGC, Jakarta.

Cancer, U.S. Departement of Health and Human Service, NIH 71, Publications, Washington DC, www.cancer.gov, update: 24 Juni 2014

Dalimartha, S., 2004. Kanker Serviks. In: Dalimartha, S., ed. Deteksi Dini Kanker \& Simplisia Antikanker. Jakarta: Penebar Swadaya, 14-18.

Depkes RI, 2009, Undang-Undang Republik Indonesia Nomor 44 Tahun 2009 Tentang Rumah Sakit Departemen Kesehatan Republik Indonesia, Jakarta.

Diananda, R., 2007, Mengenal Seluk Beluk Kanker, Yogyakarta: Katahati.

Emilia, O., 2010, Bebas Ancaman Kanker Serviks, Media Presindo, Yogyakarta. 
Fauziah, M. R., et al, 2011, Deteksi Dini Kanker Serviks pada Pusat Pelayanan Primer di Lima Wilayah DKI Jakarta, Volum: 61, Nomor: 11, Fakultas Kedokteran Universitas Indonesia, Jakarta.

FIGO Committee on Gynecologic Oncology, 2006, Staging Classifications and clinical practice Guidelines for Gynecological cancers, Available from https:// www.figo.org/files/figo-corp/docs/staging booklet.pdf (Accessed: 18 April 2014)

Fitriana, A. N., 2012, Kualitas Hidup Pada Penderita Kanker Serviks Yang Menjalani Pengobatan Radioterapi, Jurnal Psikologi Klinis dan Kesehatan Mental, Vol. 1 No. 02, Juni 2012, Fakultas Psikologi Universitas Airlangga Surabaya, update: 26 Juni 2014.

Gale, D., \& Charette, J., 2000, Rencana asuhan keperawatan onkologi.Hal 75-77, Jakarta: EGC

Hamilton, S., 2014, How Long Is Chemotherapy Given Cancer Alliance For Research, Education, And Survivorship, http://chemocare.com/chemotherapy/whatis-chemotherapy/how-long-ischemotherapygiven.aspx\#.U4b6MKAWeaR (20 Juni 2014)

Kaufman, R. H., Adam, E., Vonka, V., 2000, Human papillomavirus infection, and cervical carcinoma. In: Clinical Obstetrics and gynecology, vol 43, number 2, Lippincott Williams \& Wilkins, Hal. 363373.
Kepmenkes, 2010, Keputusan Menteri Kesehatan Republik Indonesia Nomor: 796/MENKES/SK/VIII/2010 Tentang Pedoman Teknis Pengendalian Kanker Payudara dan Kanker Leher Rahim, Menteri Kesehatan Republik Indonesia, Jakarta.

Kepmenkes, 2013, Formularium Nasional Kendalikan Mutu dan Biaya Pengobatan. Pusat Komunikasi Publik Sekretariat Jenderal Kementerian Kesehatan Republik Indonesia. Jakarta.

NCI (National Cancer Institute), 2008, What You Need To Know About Cervical

Oktaviani, D., 2012, Analisis biaya pengobatan kanker serviks sebagai pertimbangan dalam penetapan pembiayaan kesehatan berdasarkan INA-DRG's di RSUD Dr. Moewardi (Tesis). Yogyakarta: Fakultas Farmasi, Universitas Gadjah Mada.

Samadi, 2010, Yes, I Know Everything About Kanker Serviks, Hal 14-17, Tiga Serangkai, Solo.

Vogenberg, F., R., 2001, Introduction To Applied Pharmacoeconomics. Editor: Zollo S. McGraw-Hill Companies, USA

Weycker, D., et al, 2008, Cost of neutropenic complications of chemotherapy, European Society for Medical Oncology, Available from http://www.annonc.oxfordjournals.org, update: 26 Juni 2014.

Wiknjosastro, H., 2005, Ilmu Kebidanan, hal: 2023, Yayasan Bina Pustaka Sarwono Prawirohardjo, Jakarta. 